\title{
Path Analysis on the Biological and Social-Economic Determinants of Anemia in Pregnant Mothers in Bantul, Yogyakarta
}

\author{
Mulya Cunda Ratu Reso'), Yulia Lanti Ratna Dewi²), Uki Retno Budihastuti3) \\ 1)Masters Program in Public Health, Universitas Sebelas Maret \\ 2) Faculty of Medicine, Universitas Sebelas Maret \\ 3)Department of Obstetrics and Gynecology, Dr. Moewardi Hospital, Surakarta
}

\begin{abstract}
Background: Anemia in pregnant women is one of the public health problems that is still considered as a serious problem. The most important things in handling cases of anemia in pregnant women is to pay attention to biological and socio-economic factors in pregnant women. This study aimed to determine the effect of biological and socio-economic factors on the incidence of anemia among pregnant women.

Subjects and Method: This was a cross sectional study conducted in Bambanglipuro community health center, Bantul, Yogyakarta, from March to April 2019. A sample of 200 pregnant women was selected by fixed disease sampling. The dependent variable was anemia. The independent variables were age, gestational age, parity, birth spacing, education, income, adherence to iron tablet consumption, contraceptive use before pregnancy, dietary pattern, and body mass index (BMI). The data were collected by questionnaire and analyzed by path analysis.

Results: The risk of anemia in pregnant women was directly and positively affected by education $<$ Senior high school $(b=1.92 ; 95 \% \mathrm{CI}=0.67$ to $3.17 ; \mathrm{p}=0.003)$, age $<20$ or $\geq 35$ years old $(\mathrm{b}=1.27$; $95 \% \mathrm{CI}=0.09$ to $2.46 ; \mathrm{p}=0.036)$, parity $\geq 3$ times $(\mathrm{b}=1.57 ; 95 \% \mathrm{CI}=0.42$ to $2.72 ; \mathrm{p}=0.007)$, birth spacing $<2$ years $(\mathrm{b}=2.58 ; 95 \% \mathrm{CI}=1.23$ to $3.93 ; \mathrm{p}<0.001)$, gestational age (II and III trimesters) $(b=2.07 ; 95 \% \mathrm{CI}=0.69$ to $3.45 ; \mathrm{p}=0.003)$, $\mathrm{BMI}<18.5(\mathrm{~b}=3.21 ; 95 \% \mathrm{CI}=1.98$ to $4.44 ; \mathrm{p}<0.001)$, and irregular iron tablet consumption $(\mathrm{b}=1.46 ; 95 \% \mathrm{CI}=0.31$ to $2.62 ; \mathrm{p}=0.013)$. It was indirectly affected by education, history of contraceptive use, dietary pattern, and family income.

Conclusion: The risk of anemia in pregnant women is directly and positively affected by education $<$ Senior high school, age $<20$ or $\geq 35$ years old, parity $\geq 3$ times, birth spacing $<2$ years, gestational age (II and III trimesters), BMI <18.5, and irregular iron tablet consumption. It is indirectly affected by education, history of contraceptive use, dietary pattern, and family income.
\end{abstract}

Keywords: anemia, iron tablet consumption, dietary pattern, path analysis

\section{Correspondence:}

Mulya Cunda Ratu Reso. Masters Program in Public Health, Universitas Sebelas Maret. Jl. Ir. Sutami 36A, Surakarta 57126, Central Java. Email: mulyacund@gmail.com. Mobile: 082138095480

\section{BACKGROUND}

Anemia is a condition where the content of red blood cells in the body is small, while red blood cells contain hemoglobin which aimed to carry oxygen to all body tissues (Proverawati, 2011). Anemia is one of the global health problems, where there are 56 million women worldwide and two thirds of them are anemic. WHO targets that in 2025 anemia in women of reproductive age can be reduced by $50 \%$, given that anemia is the second leading cause of disease in the world and is set to be the most serious public health problem (Soh et al., 2015).

Anemia in pregnant women occurs due to physiological changes in the body during pregnancy, namely hemodilution resulting in blood hemoglobin levels of less than 12g / dL (Huang et al., 2015). The incidence of anemia in pregnant women can 
Journal of Maternal and Child Health (2019), 4(6): 23-34

https://doi.org/10.26911/thejmch.2019.04.06.03

threaten the health of the mother and the fetus. Anemia in developing countries became a serious problem because the impact caused by anemia can contribute to maternal and fetal death(Sharma and Shankar, 2010).

The proportion of anemia in pregnant women in Indonesia has increased in 2018, which was $48.9 \%$ compared to 2013 , which was 37.1\% (Basic Health Research, 2018). Bantul Health Service data in 2018 showed that there were $15.18 \%$ of pregnant women have anemia and Bambanglipuro Health Center was one of the Health Center with the highest anemia rate of $30.66 \%$ of the total 473 pregnant women (Bantul Health Office, 2018).

Anemia in pregnant women was influenced by several risk factors, namely biological factors and socio-economic factors consisting of maternal age, gestational age, parity, distance of pregnancy, education, income, body mass index, food consumption patterns, contraceptive use before pregnancy, and compliance in the consumption of blood tablets. Pregnant women with higher education would certainly pay attention and provide the best for their health and the fetus, so that the mother can overcome the problem of anemia during pregnancy (Soh et al., 2015).

Mothers who were less than 20 years old would have an impact on fetal plant disorders because the mother was still in the growth stage and the mother who was $\geq 35$ years old has a risk of decreasing iron in the body so that it can cause anemia (Demmouche et al., 2012). Pregnant women with gestational age of 2nd TM and 3rd TM have a higher risk of anemia than pregnant women who were in 1st TM (Lebso et al., 2017).

A short birth spacing can have a detrimental effect on maternal hemoglobin levels so that the mother experienced ane- mia (Vehra et al, 2012). This can also affect the mother to have more than 3 parity and increase the risk of anemia. Women who have parity 3 times or more can be affected by anemia by three times higher than mothers with parity less than 3 (Bencaiova et al., 2012).

Pregnant women can also experience anemia if they have a poor consumption pattern so that it can be said that anemia can be overcome if the mother consumed foods that are rich in iron (Lebso et al., 2017), in addition, consumption patterns can also affect maternal body mass index. Mothers with less body mass index were susceptible to anemia, because the body mass index of pregnant women who were not anemic was higher than those who suffer from anemia (Sholeye et al., 2017). Fulfillment of iron in pregnant women must be supported by income in the family, if income in the family was low, it was likely that the mother would not get good nutrition during pregnancy so that it can lead to anemia(Soh et al., 2015).

Iron status in pregnant women can also be influenced by the amount of blood loss in the mother during menstruation which was likely caused by the use of contraceptive methods. The use of hormonal contraception before pregnancy can reduce $50 \%$ of menstrual blood loss, which was only $13.6 \%$ reduced iron in women who use hormonal contraception (Bencaiovaet al., 2012).

To reduce the risk of anemia, it can be affected by consuming blood tablets, if regular pregnant women consume blood tablets, the risk of pregnant women experiencing anemia becomes smaller and vice versa (Viveki et al., 2012).

This study aims to analyze biological and socio-economic factors associated with anemia among pregnant women in Bantul, Yogyakarta, Indonesia. 


\section{SUBJECTS AND METHOD}

\section{a. Study Design}

This study was an analytical study with an observational study design and used a cross sectional approach. This research was conducted in the Bambanglipuro Health Center area, Bantul Regency, Yogyakarta in March - April 2019.

\section{b. Population and Sample}

The study population was all pregnant women in Bambanglipuro health center, Bantul, Yogyakarta. A sample of 200 pregnant women was selected by fixed disease sampling.

\section{c. Study Variables}

The dependent variable was anemia. The independent variables were maternal age, gestational age, parity, birth spacing, education, income, dietary pattern, BMI, iron tablet consumption, and history of contraceptive use.

\section{d. Operational Definition of Vari- ables}

Anemia of pregnancy was the condition of pregnant women who have hemoglobin levels in their blood <11 g / dL. The data were measured by $\mathrm{Hb}$ meter.

Maternal age was the period of time (year) experienced by pregnant women from birth to the data collection. The data were collected by questionnaire.

Gestational age was the length of maternal gestational age (weeks) at the time of the data were taken. The data were collected by questionnaire.

Maternal education was the last formal education level attained by mother. The data were collected by questionnaire.

Family income was the average income obtained by the mother and family to fulfill their needs every day for a month in the amount of rupiah. The data were collected by questionnaire.

Parity was the number of mothers giving birth to children both living and dead. The data were collected by questionnaire.

Birth spacing was the time lag between the mother's current pregnancy and the mother's previous pregnancy. The data were collected by questionnaire.

Body mass index was body weight status in the mother as measured by examination of body weight and height. Data on maternal height was measured by statumeter. Data on maternal weight was measured by weight scale.

Dietary pattern was the eating habits of pregnant women who emphasized the type of food and the frequency of food consumed by pregnant women every day consisting of carbohydrates, proteins, vitamins, and minerals. The data were measured by food frequency questionnaire.

History of contraceptive use before pregnancy was the type or method of contraception that mothers use in preventing pregnancy. The data were collected by questionnaire.

Iron tablet consumption adherence was adherence of the mother in consuming the blood tablets that have been given by health personnels. The data were collected by questionnaire.

\section{e. Data Analysis}

Univariate analysis was performed to determine the characteristics of each variable described in $\mathrm{n}$ and \%. Bivariate analysis with Chi square test to find out the effect of independent variable on the risk of anemia. Multivariate data analysis in this study used path analysis to find out the direct or indirect effects of independent variables on the risk of anemia in pregnant women.

\section{f. Research Ethics}

Research ethics include informed consent, anonymity, confidentiality, and research ethics. The research ethics was obtained from Research Ethics Committee at Dr. 
Journal of Maternal and Child Health (2019), 4(6): 23-34

https://doi.org/10.26911/thejmch.2019.04.06.03

Moewardi Hospital, Surakarta, Central Java, with number: 252/ III / HREC / 2019.

\section{RESULTS}

\section{Sample Characteristics}

Table 1 described that pregnant women who have gestational age in the first trimester were 84 (42\%). 106 (53\%) pregnant women were $<20$ or $\geq 35$ years old. There were 108 (54\%) pregnant women who have parity $\geq 3$ times and 96 (48\%) pregnant women who have a pregnancy distance of $<2$ years. The average family income had low income $(51.5 \%)$. The lack of dietary pattern was 122 (61\%) of pregnant women with less body mass index of pregnant women by 106 (53\%). The number of pregnant women who did not use contraception was higher, who were 96 (48\%) pregnant women.

Table 1. Sample characteristics

\begin{tabular}{|c|c|c|}
\hline Characteristics & $\mathbf{N}$ & $\%$ \\
\hline \multicolumn{3}{|l|}{ Gestational Age } \\
\hline 1st Trimester & 84 & 42 \\
\hline 2nd Trimester & 71 & 35.5 \\
\hline 3rd Trimester & 45 & 22.5 \\
\hline \multicolumn{3}{|l|}{ Maternal Age } \\
\hline$<20$ or $\geq 35$ years old & 106 & 53 \\
\hline $\begin{array}{l}20-35 \text { years old } \\
\text { Parity }\end{array}$ & 94 & 67 \\
\hline$\geq 3$ & 108 & 54 \\
\hline$<3$ & 92 & 46 \\
\hline \multicolumn{3}{|l|}{ Birth spacing } \\
\hline$<2$ years & 96 & 48 \\
\hline$\geq 2$ years & 104 & 52 \\
\hline \multicolumn{3}{|l|}{ Maternal Education } \\
\hline Bachelor & 15 & 7.5 \\
\hline High school & 72 & 37.5 \\
\hline Junior high school & 84 & 42 \\
\hline Elementary school & 26 & 13 \\
\hline \multicolumn{3}{|l|}{ Body Mass Index } \\
\hline Low BMI & 106 & 53 \\
\hline Normal BMI & 78 & 8 \\
\hline Excess BMI & 16 & 39 \\
\hline \multicolumn{3}{|l|}{$\begin{array}{l}\text { Maternal Dietary } \\
\text { Pattern }\end{array}$} \\
\hline Lack of Diet & 122 & 61 \\
\hline Good Diet & 78 & 78 \\
\hline
\end{tabular}

Income

\begin{tabular}{lcc}
\hline $\begin{array}{l}<\text { regional minimum } \\
\text { wage }\end{array}$ & 103 & 51.5 \\
\hline $\begin{array}{l}\text { Z regional minimum } \\
\text { wage }\end{array}$ & 97 & 48.5 \\
\hline $\begin{array}{l}\text { Iron tablet } \\
\text { consumption }\end{array}$ & & \\
\hline Adhere & 137 & 68.5 \\
\hline Not Adhere & 63 & 31.5 \\
\hline Contraception use & & \\
\hline $\begin{array}{l}\text { Hormone } \\
\text { Non Hormone }\end{array}$ & 78 & 39 \\
\hline No Contraception & 26 & 13 \\
\hline
\end{tabular}

\section{Bivariate Analysis}

Table 2 showed that the risk of anemia was more likely to occur in II and III trimesters $(\mathrm{OR}=3.27 ; \mathrm{p}<0.001)$, age $<20$ or $\geq 35$ years old ( $\mathrm{OR}=15.65 ; \mathrm{p}<0.001)$, parity $\geq 3$ times $(\mathrm{OR}=7.45 ; \mathrm{p}<0.001)$, birth distance $<2$ years $(\mathrm{OR}=8.14 ; \mathrm{p}<0.001)$, irregular iron tablet consumption $(\mathrm{OR}=5.23 ; \mathrm{p}<0.001)$, poor dietary pattern $(\mathrm{OR}=14.89 ; \mathrm{p}$ $<0.001)$, low education $(\mathrm{OR}=14.94 ; \mathrm{p}$ $<0.001)$, BMI <18.5 (OR=17.14; $\mathrm{p}<0.001)$, using non-hormonal contraception ( $\mathrm{OR}=$ 4.33; $\mathrm{p}<0.001)$, low income $(\mathrm{OR}=32.25$; $\mathrm{p}<0.001)$.

\section{Path Analysis \\ a. Model Specification}

The relationship between the variables studied would be described in the model specifications. There were 11 variables measured in this study, namely, maternal age, gestational age, pregnancy distance, number of labor, education, income, body mass index, food consumption pattern, compliance with blood tablet consumption, and the use of contraception before preg nancy and anemia.

\section{b. Model Identification}

Measured variables include:

1) Total measured variable : 11

2) Endogenous Variable : :1

3) Exogenous variables : :4

Number of parameters $\quad: 14$ 
The formula for the degree of freedom (df) was: $\mathrm{df}=$ (number of measured variables $\mathrm{x}$ (number of measured variables +1 ) / 2) (endogenous variables + exogenous variables + number of parameters)

$=(11 \times(11+1) / 2)-(1+4+14)$

$=66-19$

$=47$
The result of the degree of freedom (df) was 47 which mean that over identified or path analysis can be done.Table 3 showed the results of path analysis. There was a direct and positive effect of mothers who were <high school and the incidence of anemia, and it was statistically significant $(b=1.92 ; 95 \% \mathrm{CI}=0.64$ to $3.17 ; \mathrm{p}=0.003)$.

Table 2. Bivariate analysis

\begin{tabular}{|c|c|c|c|c|c|c|c|c|}
\hline \multirow{2}{*}{ Independent Variables } & \multicolumn{2}{|c|}{ Anemia } & \multicolumn{2}{|c|}{$\begin{array}{c}\text { Non } \\
\text { Anemia }\end{array}$} & \multicolumn{2}{|c|}{ Total } & \multirow{2}{*}{$\mathbf{O R}$} & \multirow{2}{*}{$\mathbf{p}$} \\
\hline & $\mathbf{N}$ & $\%$ & $\mathbf{N}$ & $\%$ & $\mathbf{N}$ & $\%$ & & \\
\hline \multicolumn{9}{|l|}{ Gestational Age } \\
\hline I Trimester & 28 & $33 \cdot 3$ & 56 & 66.7 & 116 & 100 & \multirow[t]{2}{*}{3.27} & \multirow[t]{2}{*}{$<0.001$} \\
\hline II and III Trimester & 72 & 62.1 & 44 & 37.9 & 84 & 100 & & \\
\hline \multicolumn{9}{|l|}{ Age } \\
\hline$<20$ or $\geq 35$ years old & 80 & 79.2 & 21 & 20.8 & 101 & 100 & \multirow{2}{*}{15.65} & \multirow[t]{2}{*}{$<0.001$} \\
\hline $20-35$ years old & 20 & 20.2 & 79 & 79.8 & 99 & 100 & & \\
\hline \multicolumn{9}{|l|}{ Number of Labor } \\
\hline$<3$ times & 23 & 25 & 69 & 75 & 92 & 100 & \multirow{2}{*}{$7 \cdot 45$} & \multirow[t]{2}{*}{$<0.001$} \\
\hline$\geq 3$ times & 77 & 71.3 & 31 & 28.7 & 108 & 100 & & \\
\hline \multicolumn{9}{|l|}{ Birth spacing } \\
\hline$<2$ years & 72 & 75 & 24 & 25 & 96 & 100 & \multirow[t]{2}{*}{8.14} & \multirow[t]{2}{*}{$<0.001$} \\
\hline$\geq 2$ years & 28 & 26.9 & 76 & 73.1 & 104 & 100 & & \\
\hline \multicolumn{9}{|l|}{ Iron tablet consumption } \\
\hline Adhere & 48 & 76.2 & 15 & 23.8 & 63 & 100 & \multirow[t]{2}{*}{5.23} & \multirow[t]{2}{*}{$<0.001$} \\
\hline Not adhere & 52 & 38 & 85 & 62 & 137 & 100 & & \\
\hline \multicolumn{9}{|l|}{ Maternal dietary pattern } \\
\hline Poor & 87 & 73.7 & 31 & 26.3 & 118 & 100 & \multirow[t]{2}{*}{14.89} & \multirow[t]{2}{*}{$<0.001$} \\
\hline Good & 13 & 15.9 & 69 & 84.1 & 82 & 100 & & \\
\hline \multicolumn{9}{|l|}{ Maternal education } \\
\hline$<$ High school & 84 & 76.4 & 26 & 23.6 & 110 & 100 & \multirow[t]{2}{*}{14.94} & \multirow[t]{2}{*}{$<0.001$} \\
\hline$\geq$ High school & 16 & 17.8 & 74 & 82.2 & 90 & 100 & & \\
\hline \multicolumn{9}{|l|}{ Body mass index } \\
\hline BMI $<18.5$ & 82 & 79.6 & 21 & 20.4 & 103 & 100 & \multirow[t]{2}{*}{17.14} & $<0.001$ \\
\hline Normal BMI & 18 & 18.6 & 79 & 81.4 & 97 & 100 & & \\
\hline Contraceptive method & & & & & & & & \\
\hline Non Hormone & 78 & 63.4 & 45 & 36.6 & 123 & 100 & 4.33 & $<0.001$ \\
\hline Hormone & 22 & 28.6 & 55 & 71.4 & 77 & 100 & & \\
\hline Income & & & & & & & & \\
\hline Low < minimum wage & 86 & $84 \cdot 3$ & 16 & $15 \cdot 7$ & 102 & 100 & 32.25 & $<0.001$ \\
\hline High $\geq$ minimum wage & 14 & 14.3 & 84 & 85.7 & 98 & 100 & & \\
\hline
\end{tabular}

Mothers with < high school education have logodd to experience anemia by 1.92 units higher than mothers who were $\geq$ HS.

Anemia was directly and positively affected by maternal age $<20$ or $\geq 35$ years old, and it was statistically significant $(\mathrm{b}=$
1.27; $95 \% \mathrm{CI}=0.09$ to $2.46 ; \mathrm{p}=0.036$ ). Mothers with age $<20$ or $\geq 35$ years old have logods for anemia by 1.27 units higher than mothers aged 20-35 years old.

Anemia was directly and positively affected by pregnant women who have 
parity $\geq 3$, and it was statistically significant (b $=1.57 ; 95 \% \mathrm{CI}=0.42$ to $2.72 ; \mathrm{p}=$ 0.007). Pregnant women who have parity $\geq 3$ have logodd for anemia by 1.57 units higher than mothers who have parity $<3$.

Anemia was directly and positively affected by pregnant women who have a pregnancy distance $<2$ years, and it was statistically significant $(\mathrm{b}=2.58$; 95\% $\mathrm{CI}=$ 1.23 to $3.93 ; \mathrm{p}<0.001$ ). Pregnant women who have a pregnancy distance of $<2$ years have logodd for anemia by 2.58 units higher than mothers who have a pregnancy distance of $\geq 2$.

Anemia was directly and positively affected by gestational age of 2nd TM and 3rd TM, and it was statistically significant $(\mathrm{b}=2.07 ; 95 \% \mathrm{CI}=0.69$ to $3.45 ; \mathrm{p}=$ o.oo3). Pregnant women who were in 2nd TM and 3rd TM have logodd to experience anemia by 2.07 units higher than pregnant women who were in $1^{\text {st }} \mathrm{TM}$.

Anemia was directly and positively affected by pregnant women who have lack of body mass index and it was statistically significant $(\mathrm{b}=3.21 ; 95 \% \mathrm{CI}=1.98$ to 4.44 ; $\mathrm{p}<0.001)$. Pregnant women who have lack of body mass index have logodd for anemia by 3.21 units higher than mothers who have normal body mass index.

Anemia was directly and positively affected by pregnant women who were obedient in taking blood tablets and it was statistically significant $(\mathrm{b}=1.46 ; 95 \% \mathrm{CI}=$ o.30 to 2.62; $\mathrm{p}=0.013$ ). Pregnant women who were obedient in consuming blood tablets had logodd to experience anemia by 1.57 units higher than those who did not obedient.

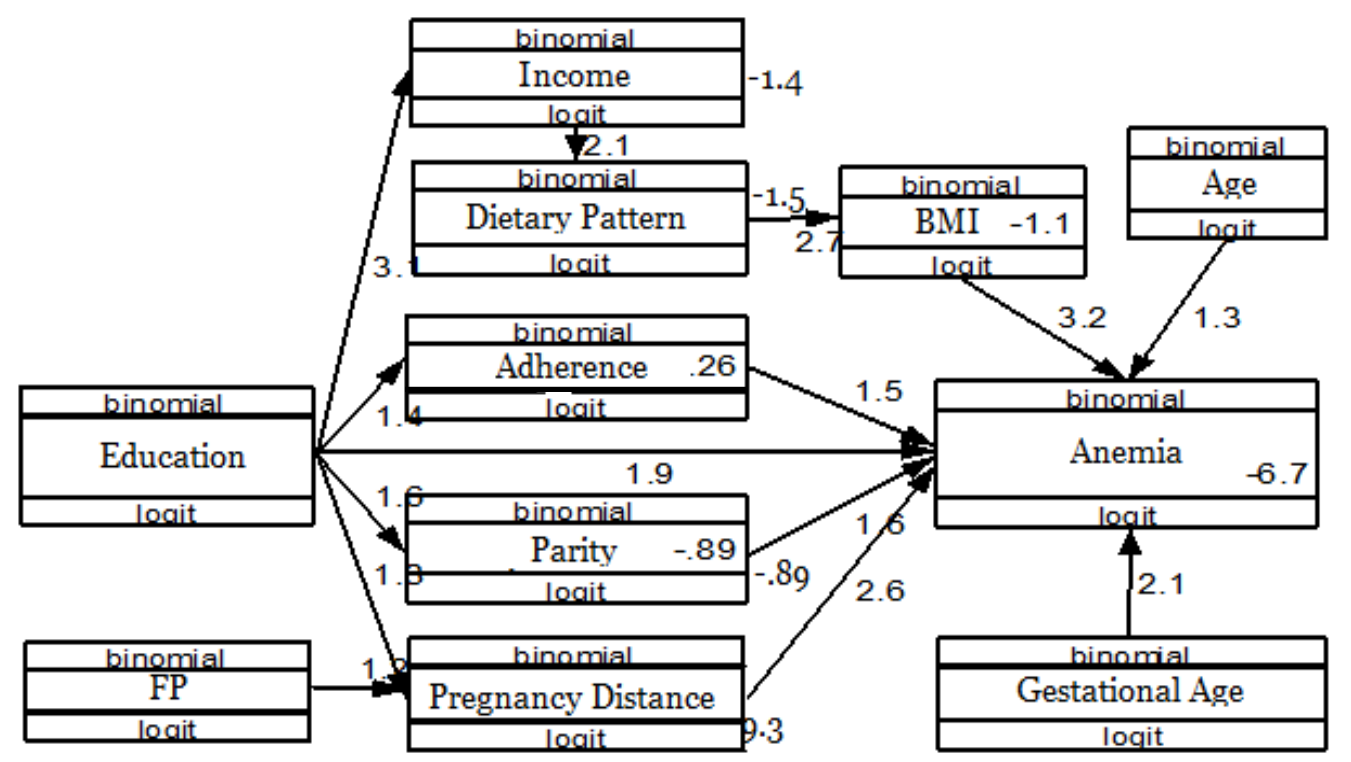

Figure 1. Path analysis model with estimation

Education of pregnant women was indirectly related to anemia through adherence in blood tablet supplementation $(\mathrm{b}=1.35$; 95\% CI $=0.68$ to 2.02 ; $\mathrm{p}<0.001)$. Education of pregnant women was indirectly related to anemia through the number of labor (b = 1.58; 95\% CI = 0.98 to 2.19; $\mathrm{p}<0.001$ ). Education of pregnant women was not di- rectly related to anemia through pregnancy distance $(\mathrm{b}=1.32 ; 95 \% \mathrm{CI}=0.70$ to $1.93 ; \mathrm{p}$ $<$ o.001). Education of pregnant women was indirectly related to anemia through family income $(\mathrm{b}=3.08$; $95 \% \mathrm{CI}=2.34$ to 3.81 ; $\mathrm{p}<0.001)$. Mothers who did not use contraception or use non-hormonal contraception were indirectly related to anemia through 
pregnancy distance $(\mathrm{b}=1.17 ; 95 \% \mathrm{CI}=0.54$ to $1.81 ; \mathrm{p}<0.001)$.

The food consumption pattern of pregnant women was indirectly related to anemia through maternal body mass index $(\mathrm{b}=2.70 ; 95 \% \mathrm{CI}=1.99$ to $3.41 ; \mathrm{p}<0.001)$. Income was indirectly related to anemia through the maternal food consumption pattern $(b=2.06 ; 95 \% \mathrm{CI}=1.41$ hto 2.71 ; $\mathrm{p}<0.001)$.

Table 3. Path analysis on factors affecting anemia among pregnant mothers

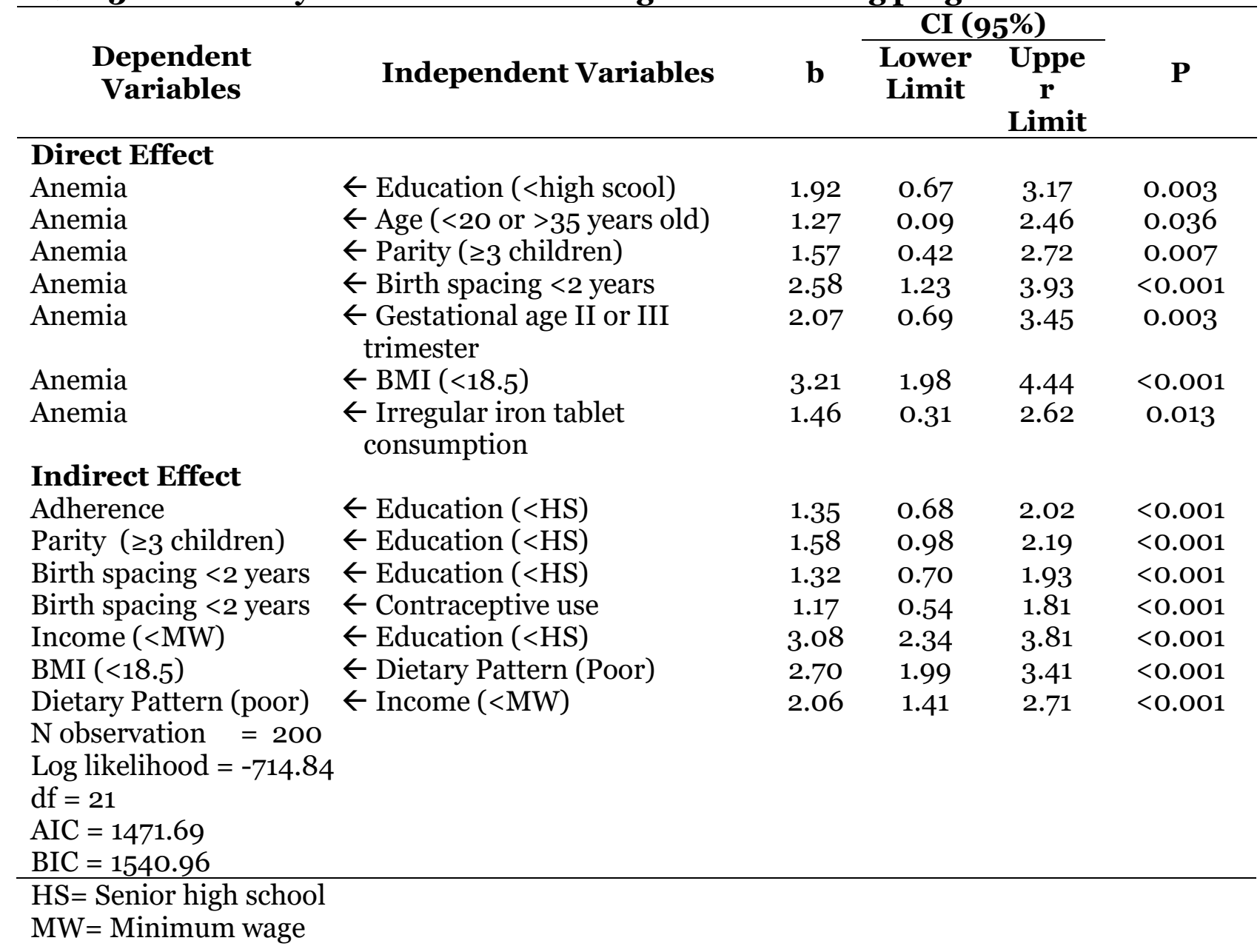

\section{DISCUSSION}

1. The effect of education on anemia among pregnant mothers

This study showed that education has a direct and positive influence on the incidence of anemia in pregnant women. The lower the maternal education, the higher the risk of anemia in pregnancy. Education also has an indirect influence on anemia through adherence to blood tablet consumption, maternal parity, pregnancy distance and family income.

Education has a significant relationship with anemia $(\mathrm{OR}=0.37 ; \mathrm{p}=0.003)(\mathrm{Si}-$ nawang et al., 2018). Daka et al. (2018) explained that higher education has been shown to significantly influence knowledge of anemia prevention knowledge during pregnancy $(\mathrm{OR}=5.03,95 \% \mathrm{CI}=1.87$ to 13.52; $p<0.001$ ). Pregnant women who have low education were found to have a maximum anemia prevalence (62.71\%) compared to pregnant women who have higher education (Bedi et al., 2015). The level of education can influence maternal behavior in daily activities. The higher the level of education, the better the level of knowledge and lead to quality life (Fauziyah, 2012). 
Journal of Maternal and Child Health (2019), 4(6): 23-34

https://doi.org/10.26911/thejmch.2019.04.06.03

\section{The effect of age on anemia in pregnant mothers}

The results of the analysis showed that maternal age $<20$ or $\geq 35$ years old had a direct and positive effect on the incidence of anemia in pregnant women. Mothers with age $<\mathbf{2 0}$ or $\geq 35$ years old have a high risk of developing anemia.

Feleke et al. (2018) stated that maternal age was related to the incidence of anemia in pregnant women $(\mathrm{OR}=1.05 ; 95 \%$ $\mathrm{CI}=1.03$ to 1.07$)$. Pregnant women who were 15-22 years old can influence the $\mathrm{Hb}$ condition in their body resulting in anemia $(\mathrm{OR}=9.89 ; \mathrm{CI}=2.68$ to 21.41$)$ (Gedefaw et al., 2015).

Age of pregnant women $\geq 35$ years old was 2.6 (95\% CI $=1.2$ to 5.6) times more likely to develop anemia than mothers aged 20-24 years old. This may be due to a decrease in serum ferritin values with an increase in age (Uche-Nwachi et al., 2010). The productive and safe age group in pregnancy was the 21-30 years old (Soh et al., 2015).

\section{The effect of parity on anemia among pregnant mothers}

The results of the analysis showed that parity has a direct and positive influence on the incidence of anemia in pregnant women. The higher the maternal parity, the higher the risk of anemia in pregnancy.

Study of Asrie (2017) stated that there was a significant relationship between parity or the number of labor with the incidence of anemia $(\mathrm{OR}=9.17$ : $95 \% \mathrm{CI}=2.15$ to 40 ; $\mathrm{p}<0.001)$. Mothers who have four or more children in Jordan have a significant relationship with anemia $(\mathrm{OR}=1.54$; 95\% $\mathrm{CI}=$ 1.22 to 1.93 ; p <0.001) (Arabyat et al., 2018).

Multiparity was more susceptible to anemia during pregnancy compared to a primigravidian mother. This was because the more often pregnant women experience labor, the more they would lose blood and cause anemia and reduce iron reserves in the body (Ouédraogo et al., 2012).

\section{The effect of pregnancy distance on anemia among pregnant mothers}

The results of the analysis showed that the distance of pregnancy has a direct and positive influence on the incidence of anemia in pregnant women. $<2$ years of pregnancy can increase the risk of anemia.

The results of this study were supported by the study of Shwetha et al. (2018) which stated that the pregnancy distance of mothers <2 years was at risk for anemia during pregnancy with a value of $\mathrm{p}=0.02$.

During the process of pregnancy and childbirth, the maternal iron reserves in the body were reduced, so it was recommended that mothers have a minimum distance of 2 years to have a new pregnancy. With such distance, it was expected to be able to prepare physically and fulfill nutrition in the maternal body so that the function of the body's organs can recover (Manuaba et al., 2013).

\section{The effect of gestational age on anemia among pregnant mothers}

The results of the analysis showed that gestational age has a direct and positive influence on the incidence of anemia in pregnant women. Mothers with gestational age of 2nd TM and 3rd TM have a high risk for anemia.

A study of Gedefaw et al. (2015)was in line with the result of this study which stated that pregnant women in the third trimester were at risk of experiencing anemia during pregnancy (OR $=11.37 ; 95 \%$ $\mathrm{CI}=4.56$ to 24.82$)$. Pregnant women with an older gestational age were at risk of anemia with $(\mathrm{OR}=0.35 ; 95 \% \mathrm{CI}=0.15$ to $0.80 ; p=0.013$ ) (Prahesti et al., 2015). This was due to an increase in trimester which caused a reduction in maternal iron reserves. 
Increasing the gestational age of the mother increased the need for iron in pregnant women. Therefore, if it was not balanced with adequate nutrition and iron intake, the mother would experience anemia as the mother's pregnancy increased. The need for iron in the third trimester was higher than the need before pregnancy, which was $5.6 \mathrm{mg} /$ day (3.54-8.80 mg/day) (Morrison et al., 2011).

\section{The Effect of Body Mass Index on} Anemia Among Pregnant Mothers

The results of the analysis showed that the body mass index of the mother has a direct and positive influence on the incidence of anemia in pregnant women. Mothers with lack of body mass index were more likely to experience anemia.

Study of Charles et al. (2010) stated that there was a significant relationship between the body mass index of pregnant women and the incidence of anemia. This was supported by studies in Ethiopia where low BMI can be a cause of anemia in pregnancy because the BMI in pregnant women who were not anemic was higher than those who have anemia (Sholeyeet al., 2017).

\section{The effect of adherence to iron tablet consumption on anemia}

The results of the analysis showed that iron tablet consumption adherence has a direct and positive influence on the incidence of anemia in pregnant women. Mothers who were not obedient in taking blood tablets were more likely to experience anemia.

The results of this study were in line with the research of Bedi et al. (2015) which explained that the prevalence of anemia was significantly higher in women who had never asked for or consumed iron and folic acid during pregnancy (27.44\% : 13.66\%).

The influence of iron and folic acid was a supplement that can increase hemoglobin, serum ferritin, and average cell volume and can reduce iron depletion rates in the third trimester (Kumar et al., 2012).

\section{The effect of contraception use before pregnancy on anemia}

The results of the analysis showed that the use of family planning has an indirect and positive effect on the incidence of anemia in pregnant women. Mothers with nonhormonal birth control and those who did not use family planning were at high risk of anemia.

Gebremedhin et al. (2018) stated that hormonal contraceptive use was able to reduce the chance of anemia by $38 \%(\mathrm{AOR}=$ 0.62 (95\% CI= 0.57 to 0.67 ) and the duration of use of maternal hormonal contraception was able to influence the decline in the rate of stable anemia.

The protective effect of contraception on $\mathrm{Hb}$ was probably due to a reduction in menstrual bleeding that can be reduced by $50 \%$ among users of contraception (Bellizzi et al., 2018).

\section{The effect of dietary pattern on anemia among pregnant mothers}

The results of the analysis showed that food consumption patterns have an indirect and positive influence on the incidence of anemia in pregnant women. Mothers with poor food consumption patterns would increase the risk of anemia.

Ansariet al. (2017) stated that pregnant women who have anemia have a lower body mass index score. This was due to a lack of nutrition in pregnant women and this implied that there was inadequate calorie and nutritional intake in pregnant women. A mother who has a poor diet would be at risk to have lack of nutritional intake in her body (Oktiriyani et al., 2014). A pregnant woman was recommended to consume various types of food with the amount or portion according to their needs during pregnancy (Ministry of Health, 2014). 


\section{The effect of income on anemia among pregnant mothers}

The results of the analysis showed that income has an indirect and positive influence on the incidence of anemia in pregnant women. Income < regional minimum wage increased the risk of mothers getting anemia. The condition of families with high income was able to reduce the incidence of anemia by $1 / 10$ times compared with the condition of families with low income (Andriani et al. 2016). Low family income did not only affect or cause anemia in pregnant women but was also at risk for conditions of micronutrient deficiency in pregnant women themselves (Darnton-Hill dan Mkparu, 2015).

\section{AUTHOR CONTRIBUTION}

Mulya Cunda Ratu Reso, the main author, played a role in collecting data and processsed data analysis. Yulia Lanti Retno Dewi examined the conceptual framework and suggested the methodology. Uki Retno Budihastuti interpreted the results of data analysis and suggested the discussion.

\section{FUNDING AND SPONSORSHIP}

This study used the authors' own fund.

\section{CONFLICT OF INTEREST}

\section{None.}

\section{ACKNOWLEDGEMENT}

We would like to say thank you to village midwives in the Bambanglipuro Health Center area and those who have participated in this study.

\section{REFERENCE}

$\overline{\text { Andriani Y, Respati SH, Astirin OP (2016). }}$ Efektivitas Kelas Ibu Hamil dalam Upaya Pencegahan Anemia dalam Kehamilan di Banyuwangi, Jawa Timur (Effectiveness of classes of pregnant women in the prevention of anemia in pregnancy in Banyuwangi, East Java). Journal of Maternal and Child Health. 1(4): $\quad 230-241$.doi.org/10.26911/thejmch.2016.01.04.04.

Ansari NB, Salma HB, Rozina K, Hillary H, Imtiaz J, Omrana P, Nancy M, Elizabeth MM, Robert LG (2009). Anemia Prevalence and Risk Factors in Pregnant Women in an Urban Area of Pakistan. Food Nuts Bull. 29 (2):132139.https://www.ncbi.nlm.nih.gov/p mc/articles/PMC3917507/.

Arabyat RM, Ghaith A, Ghaith MA (2018). Prevalance and risk factors of anaemia among ever-married women in Jordan. East Mediter Health Journal. 24 (10): 1-15. doi.org/10.26719/emhj.18.074.

Asrie F (2017). Prevalence of Anemia and its associated factors among pregnant women receiving antenatal care at Aymiba Health Center, Nothwest Ethiopia. Journal of Blood Medicine. (8): 35-40. http://dx.doi.org/10.2147/JBM.S134932.

Bedi R, Rekha A, Rashmi G, Swati P, Rakesh $S$ (2015). Maternal Factors of anemia in $3^{\text {rd }}$ trimester of pregnancy and its association with fetal outcome. International Multispecialty Journal of Health. 1 (7): 9-16. https://pdfs.semanticscholar.org/foa2/77f18d7c5be4a6b2ffc19cd5cd30c9e81524.pdf.

Bellizzi S, Mohamed MA (2018). Effect of oral contraception on anemia in 12 low and middle-income countries. Elsevier. (97): 236-247.doi.org/10.1016/j.contraception.2017.11.001.

Bencaiova G, Tilo B, Christian B (2012). Anemia-prevalence and risk factors in pregnancy. European Journal of Internal Medicine. (23):529-533.doi:10.1016/j.ejim.2012.04.008.

Charles AM, Campbell-Stennett D, Yatich 
N, Jolly PE (2010). Predictors of anemia among pregnant women in Westmoreland, Jamaica. Health Care Women Int. 31(7): 585-598. doi:10.1080/07399331003710541

Daka KB, Jayanthigopal, Dereja BD (2018). Assessment of knowledge and practice towards prevention of anemia among pregnant women attending antenatal care at government hospitals in West Shoa Zone, Ethiopia. Journal of Health Medicine, and Nursing. (50): 31-40. https://www.k4health.org/sites/default/files/daka_et_al_2018_1.p df

Darnton-hill I, Mkparu UC (2015). Micronutrients in pregnancy in low- and middle-income countries. (7): 17441768. doi: 10.3390/nu7031744.

Demmouche A, Khelil S, Moulessehoul S (2011). Anemia among pregnant women in the Sidi Bel Abbes Region (West Algeria). Journal of Blood Disorders and Transfusion. 2(3): 113-119. doi: 10.4172/2155-9864.1000113.

Dinas Kesehatan Kabupaten Bantul (Bantul District Health Office) (2018). Profil Kesehatan Kabupaten Bantul 2019 (Bantul Regency Health Profile 2019). Bantul.

Fauziyah Y (2012). Obstetri Patologi (Obstetrics Pathology). Yogyakarta: Nuha medika

Gebremedhin S, Anteneh A (2018). Association between type of contraceptive use and haemoglobin status among women of reproductive age in $24 \mathrm{Sub}$ Saharan Africa Countries. BMJ Sex Reprod Health 2018 (o): 1-7. doi. org/10.1136/bmjsrh- 2018- 200178.

Gedefaw L, Asrat A, Yaregal A, Andualem M (2015). Anemia and associated factors among pregnant women attending antenatal care clinic in Wolayita Sodo Town, Southern Ethiopia. Ethiop J
Health Sci. (2): 155-162.http://dx.doi.org/10.4314/ejhs.v25i2.8.

Huang LL, Gowreesunkur P, Su MW, Lin $\mathrm{LZ}$, Hui $\mathrm{T}$ (2015). The influence of iron-deficiency anemia during the pregnancy on preterm birth and birth weight in South China. Journal of Food and Nutrition Research 3(9): 570-574. doi:10.12691/jfnr-3-9-2.

Kemenkes RI (2014). Pedoman gizi seimbang (Balanced Nutrition Guidelines). http://kesmas.kemkes.go.id/perpu/konten/permenkes/pmkno.41ttg-pedoman-gizi-seimbang.

Lebso M, Anchamo A, Eskindir L (2017). Prevalence of anemia and associated factors among pregnant women in Southern Ethiopia: A community based cross-sectional study. Journal Plos One. 12(12): 1-11.doi.org/10.1371/journal.pone.0188783.

Manuaba IBG, IA Chandranita M, IBG Fajar $M$ (2013). Introduction to obstetrics lecture. Jakarta: EGC

Morrison JC, Marc RPJ (2011). Anemia associated with pregnancy. Global Libary of Women's Medicine. doi 10.3843/GLOWM.10164.

Oktriyani O, Juffrie M, Astiti D (2014). Pola makan dan pantangan makan tidak berhubungan dengan kekurangan energi kronis pada ibu hamil (Diet and dietary restrictions are not associated with chronic energy deficiency in pregnant women). Indonesian Journal of Nutrition and Dietetics (IJND) 2(3): 159-169. doi.-org/10.21927/ijnd.2014.2(3).159-169.

Ouedraogo S, Florence BL, Valerie B, BichTram H, Ghislain KK, Manfred MKA, Nadine F, Achille M, Philippe D, Michel C (2012). Malaria and gravidity interect to modify maternal haemoglobin concentrations during preg- 
nancy. Malaria Journal. 11: 348.doi: 10.1186/1475-2875-11-348.

Kumar P, Pore P, Patil U (2012). Maternal anemia and its impact on parinatal outcome in a tertiary care Hospital of Pune, in Maharashtra. Indian Journal of Basic \& Applied Medical Research; 1 (2): 111-119.ijbamr.com/pdf/PDF134 ISSUE2.pdf.

Prahesti R, Indarto D, Akhyar M (2016). Analysis of factors associated with anemia in pregnant women at Prambanan Health Center, Sleman, Yogyakarta. Journal Maternal and Child Health. 1(2): 131-137. doi.org/10.26911/thejmch.2016.01.02.08

Proverawati A (2011). Anemia dan Anemia kehamilan (Anemia and pregnancy anemia). Yogyakarta: Nuha Medika

Riset Kesehatan Dasar (Basic Health Research (2018). Badan Penelitian Dan Pengembangan Kesehatan. Departemen Kesehatan, Republik Indonesia. Jakarta. (Health Research and Development Agency. Ministry of Health, Republic of Indonesia. Jakarta).

Sinawangwulan IP, Dewi YLR, Wekadigunawan CSP (2018). Relationship between social demography, nutrition intake, cultural trust, and incidence of anemia in pregnant women in Karanganyar, Central Java. Journal Maternal and Child Health. 3(2): 128-137.doi.org/10.26911/thejmch.2018.03.02.0.

Sharma JB, Meenakshi S (2010). Anemia in pregnancy. JIMSA. 23 (4):253-26o. http://medind.nic.in/jav/t10/i4/javt1 oi4p253.pdf.

Sholeye OO, Victor JA, Tessie OS (2017). Anemia in pregnancy and its associated factors among primary care clients in Sagamu, Southwest, Nigeria: A faci- lity based study. Journal of Family Medicine and Primary Care. 6(2): 323-329. doi:10.4103/jfmpc.jfmpc_74_16.

Shwetha PKN (2018). Prevalence of anemia among pregnant women-A crosssectional study. International Journal of Medical Science and Public Health. 7: 1023-102.doi: 10.5455/ijmsph. 20180514622092018.

Soh KL, Eusni RMT, Salimah J, Soh KG, Norhaslinda BR, Rosna AR (2015). Anemia among antenatal mother in urban Malaysia. Journal of Biosciences and Medicines.(3): 6-11. http://dx.doi.org/10.4236/jbm.2015.33002.

Uche-Nwachi EO, Odekunle A, Jacinto S, Burnett M, Clapperton M, David Y, Durga S, Greene K, Jarvis J, Nixon C, Seereeram R, Poon-King C, Singh R (2010). Anemia in pregnancy assosiations with parity, abortions and child sapsing in primary healthcare clinic attendees in Trinidad and Tobago. African Health Sciences. 10(1): 66-70. https://www.ncbi.nlm.nih.gov/pubmed/20811527

Vehra S, Ejaz MAQ, Farooq A (2012). Effect of sociodemographic and gestational status on the development of iron deficiency anemia in pregnant women. Pakistan Journal of Nutrition 11 (7): 545-549.doi: 10.3923/pjn.2012.643.647 .

Viveki RG, Halappanavar AB, Vivek PR, Halki SB, Maled VS, Deshpande PS (2012). Prevalence of Anemia and its epidemiological determinants in pregnant women. Al Ameen J Med Sci. 5(3): 216-223. http://newajms.alameenmedical.org/ArticlePDFs/AJMS\% 20V5.N3.2012\%20p\%20216-223.pdf. 